\title{
Al and PEG Effect on Structural and Physicochemical Properties of $\mathrm{CoFe}_{2} \mathrm{O}_{4}$
}

\author{
Fatemeh Mostaghni *, Yasaman Abed ${ }^{b}$ \\ ${ }^{a}$ Chemistry Department, Payam Noor University, Iran, P.O.Box: 19395-4697 \\ ${ }^{b}$ Physic Department, Payam Noor University, Iran, P.O.Box: 19395-4697
}

Received: December 04, 2016; Revised: February 07, 2017; Accepted: February 18, 2017

\begin{abstract}
In this work, pure and Alumina doped cobalt ferrite nanoparticles $\mathrm{CoFe}_{2-\mathrm{x}} \mathrm{Al}_{\mathrm{x}} \mathrm{O}_{4}($ for $\mathrm{x}=0.44)$ have been synthesized by the sol gel method. The influence of alumina doping on the morphological and mechanical properties of $\mathrm{CoFe}_{2} \mathrm{O}_{4}$ nano-particles were investigated by means of X-ray powder diffraction (XRD) and rietveld analysis. XRD analysis confirmed that the single phase formation of pure nano particles with the expected cubic inverse spinel structure with $\mathrm{Fd} 3 \mathrm{~m}$ space group and without any impurity phase. Alumina doping were led to a decrease in the crystallite size, lattice parameter, elastic constants and magnitude of moduli. It is explained on the basis of the replacement of $\mathrm{Fe}$ ions with half-filled d-shell $\left(3 \mathrm{~d}^{5}\right)$ and larger radius by $\mathrm{Al}^{3+}$ ions with a completely filled shell $\left(2 p^{6}\right)$ and smaller radius.
\end{abstract}

Keywords: Spinels, Ferrite, Cobalt ferrite, Rietveld Refinement

\section{Introduction}

Spinels of the type $\mathrm{AB}_{2} \mathrm{X}_{4}$ are one of the most interesting and important families of crystalline compounds due to their broad applications in magnetic materials, ceramics, catalysis, etc. Spinels of the type $\mathrm{A}^{2+} \mathrm{B}^{3+}{ }_{2} \mathrm{O}_{4}$ belong to a large group of composite oxides with a cubic symmetry (space group $\mathrm{Fd} 3 \mathrm{~m}$ ), where $\mathrm{A}$ and $\mathrm{B}$ are cations with variable valence. In natural spinels usually $A$ represents divalent cation, while $B$ represents trivalent cation $\left(\mathrm{A}^{2+} \mathrm{B}^{3+}{ }_{2} \mathrm{O}_{4}\right.$, so-called 2-3 spinels). ${ }^{1-3}$

Among spinel composite oxides, spinel ferrite nanoparticles have been studied for many years due to their magnetic and electrical properties. In particular, the $\mathrm{CoFe}_{2} \mathrm{O}_{4}$ has covered a broad applications including electronic devices, ferrofluids, magnetic drug delivery, microwave devices and high density information storage. ${ }^{4-9}$ Cobalt ferrite $\left(\mathrm{CoFe}_{2} \mathrm{O}_{4}\right)$ is one of the well known hard magnetic materials which has strong magnetic anisotropy, high magnetostriction, moderate magnetization, high coercivity at room temperature and high chemical stability and good electrical insulation. ${ }^{10-13}$ There are different methods which have been reported for the preparation of magnetic nanoparticles of cobalt ferrite. ${ }^{14-17}$

Cobalt ferrite is a partially inverse spinel with formula $\left(\mathrm{Co}_{\mathrm{x}} \mathrm{Fe}_{1-\mathrm{x}}\right)\left[\mathrm{Co}_{1-\mathrm{x}} \mathrm{Fe}_{1+\mathrm{x}}\right] \mathrm{O}_{4}$, formed by oxygen atoms in a closed packing structure where, $\mathrm{Co}^{2+}$ and $\mathrm{Fe}^{3+}$ occupy either tetrahedral or octahedral sites. ${ }^{18-22}$ Several researchers have reported on Ti, Y, Gd, Pr, Zn, Ni and Dy doped cobalt ferrite. ${ }^{23-28}$

The present work is focused on the effects of $\mathrm{Al}^{3+}$ doping on the structural, morphological and elastic properties of aluminium ion doped cobalt ferrite obtained via sol-gel method. The X-ray powder diffraction patterns, the microstructure and the elastic properties are discussed as a function of the $\mathrm{Al}^{3+}$ doping.

*e-mail: mostaghnif@yahoo.com

\section{Materials and Methods}

\subsection{Material}

Iron (III) nitrate nonahydrate $\mathrm{Fe}\left(\mathrm{NO}_{3}\right)_{3} \cdot 9 \mathrm{H}_{2} \mathrm{O}$, cobalt(II) nitrate hexahydrate $\mathrm{Co}\left(\mathrm{NO}_{3}\right)_{2} \cdot 6 \mathrm{H}_{2} \mathrm{O}$ and aluminium nitrate nonahydrate- $\mathrm{Al}\left(\mathrm{NO}_{3}\right)_{3} \cdot 9 \mathrm{H}_{2} \mathrm{O}$ as source of metal ions and polyethylene glycol (average molecular weight: 4000, Qualigen) as a surfactant were used. The $\mathrm{pH}$ was controlled by amonium hydroxide $\mathrm{NH}_{4} \mathrm{OH}$. All reactants were purchased from Sigma-Aldrich. Deionized water served as reacting medium.

\subsection{Synthesis of nanoparticles}

Nanocrystalline powders of $\mathrm{CoFe}_{2-\mathrm{x}} \mathrm{Al}_{\mathrm{x}} \mathrm{O}_{4}(\mathrm{x}=0$, $0.4)$ were prepared by the sol-gel method. In a typical reaction, cobalt nitrate $\left(\mathrm{Co}\left(\mathrm{NO}_{3}\right)_{2} \cdot 6 \mathrm{H}_{2} \mathrm{O}\right)$, iron nitrate $\left(\mathrm{Fe}\left(\mathrm{NO}_{3}\right)_{3} \cdot 9 \mathrm{H}_{2} \mathrm{O}\right)$, and aluminum nitrate $\left(\mathrm{Al}\left(\mathrm{NO}_{3}\right)_{3} \cdot 9 \mathrm{H}_{2} \mathrm{O}\right)$ were individually dissolved in $10 \mathrm{ml}$ of deionized water in their respective stoichiometry. The solutions were then mixed and stirred for 30 minutes at room temperature. In addition, polyethylene glycol (average molecular weight: 4000 , Qualigen) served as a surfactant for this reaction and poured into the above mixture. Then, the $25 \%$ ammonia solution was added drop by drop and stirred vigorous on a magnetic stirrer. The final $\mathrm{pH}$ of the mixture was about 8 . The resulting solution was kept under stirring at $60^{\circ} \mathrm{C}$ for 1 hour. The obtained gels were dried at $80^{\circ} \mathrm{C}$ and calcined at $500^{\circ} \mathrm{C}$ for 3 hours.

Crystal structure of nanoparticles was determined by a Bruker make diffractometer, $\mathrm{Cu}-\mathrm{K}_{\alpha} \mathrm{X}$-rays of wavelength $(\lambda=1.5406 \AA)$. The XRD patterns were recorded in the $2 \theta$ range of $10-90^{\circ}$ with a step width of $0.02 \mathrm{~s}^{-1}$. 


\subsection{Simulation analysis}

The accelrys materials studio 6.0 visualisation package was used to create the nanoparticles. The X-ray diffraction (XRD) pattern was analysed with the help of reflex module by employing rietveld refinement technique. The XRD pattern of the pure and aluminia doped $\mathrm{CoFe}_{2} \mathrm{O}_{4}$ was refined using the Fd $3 \mathrm{~m}$ space group. The Castep module was employed to calculate the structural, electronic, and elastic properties of two samples. Generalized gradient approximation (GGA) with the Perdew-Burke-Ernzerhof was used for all calculations.

\section{Results and Discussion}

\subsection{X-Ray diffraction studies}

$\mathrm{X}$-ray diffraction pattern of synthesized aluminia doped and pure $\mathrm{CoFe}_{2} \mathrm{O}_{4}$ are presented in Figure. 1.

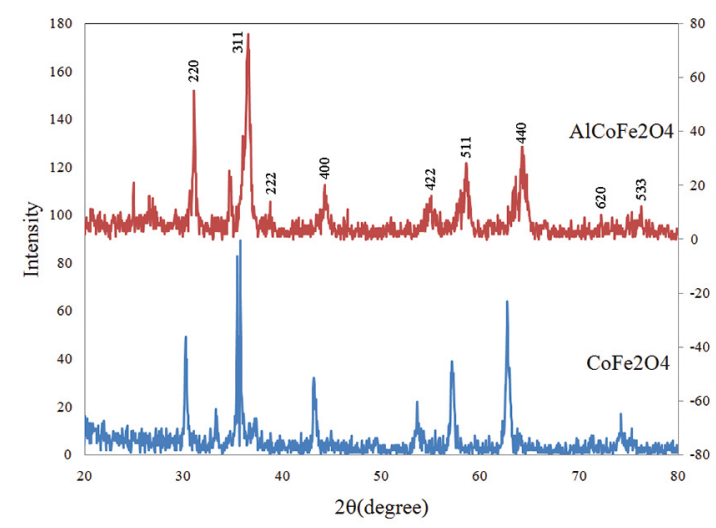

Figure 1. XRD pattern of synthesized $\mathrm{CoFe}_{2} \mathrm{O}_{4}$ and Al-dopped $\mathrm{CoFe}_{2} \mathrm{O}_{4}$

Peak details of synthesized nanoparticles sumerised in Table 1 and 2. The sharp and broad peaks in these XRD patterns, confirming the single phase formation of pure nano particles with the expected cubic inverse spinel structure with Fd3m space group and without any impurity phase. It can be observed that the intensities of the 220 planes increase and the intensity of 440 plane decrease with the addition of aluminium indicating the preference of the $\mathrm{Co}^{2+}, \mathrm{Fe}^{3+}$ and $\mathrm{Al}^{3+}$ ions by the octahedral $\mathrm{B}$ and tetrahedral A sites. Indeed, this may be indicated the redistribution of the cations in the nanostructure aluminium cobalt ferrite. From this data it is evident that the ratio of $\mathrm{Fe}^{3+}$ (oct.)/ $/ \mathrm{Fe}^{3+}$ (tet.) changes with addition of $\mathrm{Al}^{3+}$ ion. In the present case the cubic phase spinel ferrite structure for two composition is mainly due to deficit of $\mathrm{Co}^{2+}$ ions in the octahedral sites $(<85 \%)$ that leads to the absence of co-operative active Jahn-Teller distortion. The crystallite size of the nano-particles were calculated from the most intense peak (3 11 ) of XRD data using Debye-Scherer equation. The crystallite size of $\mathrm{Al}^{1+}$ doped and pure $\mathrm{CoFe}_{2} \mathrm{O}_{4}$ nano-particles were 18.9 and $24.3 \mathrm{~nm}$ respectively. The lattice constants of $\mathrm{Al}^{3+}$ doped and pure $\mathrm{CoFe}_{2} \mathrm{O}_{4}$, calculated from $\mathrm{F}(\theta)$ were 8.22 and 8.32 repectively.

As can be seen, the crystallite size and lattice constant were decreased with alumina doping. Similar results have been reported in the literature. ${ }^{29,30}$ This behavior of the lattice constant with alumina doping is due to the replacement of larger $\mathrm{Fe}^{3+}$ ions $\left(0.645^{\circ} \mathrm{A}\right)$ by smaller $\mathrm{Al}^{3+}$ ions $\left(0.535^{\circ} \mathrm{A}\right)$ in the system.

The $x$-ray density $(\rho x)$ of the samples was determined using relation given by Smith and Wijn: ${ }^{31,32}$

$$
\rho_{x}=\frac{8 M}{N_{A} a^{3}}
$$

where, $\mathrm{M}$ is the molecular weight of the composition, $\mathrm{N}_{\mathrm{A}}$ is the Avogadro's number and ' $\mathrm{a}$ ' is the lattice constant. As there are 8 formula unit in the unit cell so 8 is included in the formula. The $x$-ray density ( $\rho x)$ of alumina doped and pure $\mathrm{CoFe}_{2} \mathrm{O}_{4}$, were 3.605 and $3.746 \mathrm{~g} / \mathrm{cm}^{3}$ repectively.

It can be observed that the $\mathrm{x}$-ray density $(\rho \mathrm{x})$ decreased with alumina doping, because the decrease in molecular weight overtakes the decrease in volume of the unit cell.

\subsection{Rietveld analysis}

Various structural parameters can be determined from rietveld analysis and are found useful to explain other physical properties. ${ }^{33}$ This method is based on a least-squares fit between step-scan data of a measured diffraction pattern and a simulated X-ray-diffraction pattern.

In this study the crystalline structure of the pure and aluminia doped $\mathrm{CoFe}_{2} \mathrm{O}_{4}$ were analized in detailed by rietveld profile refinement method in reflex module. The XRD patterns for these samples have refined using the $\mathrm{Fd} 3 \mathrm{~m}$ space group (Figure 2).

The fitting quality of the experimental data is assessed by computing the parameters R-pattern factor $\mathrm{R}_{\mathrm{p}}$ and the weighted-profile factor $\mathrm{R}_{\mathrm{wp}}{ }^{34-36}$ These factors are defined as:

$$
\begin{gathered}
R_{W_{p}}=\left[\frac{\sum_{i}\left(I_{0}-I_{c}\right)^{2} w_{i}}{\sum_{i} I_{0}^{2} w_{i}}\right]^{2} . \\
R_{p}=\frac{\sum_{i}\left|y_{i o}-y_{i c}\right|}{\sum_{i} y_{i o}}
\end{gathered}
$$

Where Io and Ic are respectively observed and calculated integrated Bragg intensities (without background). $\mathrm{R}_{\mathrm{p}}$ and $\mathrm{R}_{\text {wp }}$ values for pure and aluminia doped $\mathrm{CoFe}_{2} \mathrm{O}_{4}$ were (6.01, 9.27) and $(6.91,9.30)$ respectively. The calculated $\mathrm{R}$ factors indicated that the models were correct.

Oxygen positional parameter (u) for each composite was calculated using the formulae available in the literature. Where $\mathrm{u}^{3}$ ' gives $\mathrm{u}$ assuming centre of symmetry at $(1 / 4,1 / 4$, 
Table 1. Peak analysis of XRD pattern of synthesized $\mathrm{CoFe}_{2} \mathrm{O}_{4}$

\begin{tabular}{lcccccc}
\hline $2 \theta$ [deg.] & h k 1 & FwHM [20] & d-spacing & a [A] & F $(\theta)$ & Cry.size [nm] \\
\hline 30.19 & 220 & 0.2460 & 2.9596 & 8.37 & 1.82961 & 33.4 \\
33.22 & 310 & 0.5904 & 2.6964 & 8.52 & 1.62781 & 14.1 \\
35.56 & 311 & 0.3444 & 2.5245 & 8.37 & 1.50955 & 24.3 \\
43.13 & 400 & 0.2952 & 2.0972 & 8.36 & 1.03974 & 29.0 \\
53.47 & 422 & 0.7872 & 1.7135 & 8.37 & 0.90145 & 11.3 \\
57.08 & 511 & 0.3444 & 1.6133 & 8.31 & 0.82074 & 26.3 \\
62.71 & 440 & 0.6000 & 1.4803 & 8.37 & 0.12157 & 15.5 \\
\hline
\end{tabular}

Table 2. Peak analysis of XRD pattern of synthesized Al-dopped $\mathrm{CoFe}_{2} \mathrm{O}_{4}$

\begin{tabular}{lcccccc}
\hline $2 \theta$ [deg.] & h k 1 & FwHM [20] & d-spacing & a [A] & F $(\theta)$ & Cry.size [nm] \\
\hline 30.75 & 220 & 0.1968 & 2.9068 & 8.22178 & 1.77766 & 41.8 \\
34.36 & 310 & 0.2952 & 2.6099 & 8.25323 & 1.56398 & 28.2 \\
36.20 & 311 & 0.4428 & 2.4811 & 8.22898 & 1.47009 & 18.9 \\
44.04 & 400 & 0.7872 & 2.0559 & 8.22384 & 1.16509 & 10.9 \\
54.47 & 422 & 0.7872 & 1.68453 & 8.25248 & 0.87748 & 11.4 \\
58.23 & 511 & 0.3936 & 1.58429 & 8.23221 & 0.79441 & 23.1 \\
64.11 & 440 & 0.7200 & 1.45126 & 8.20957 & 0.68597 & 13.0 \\
\hline
\end{tabular}
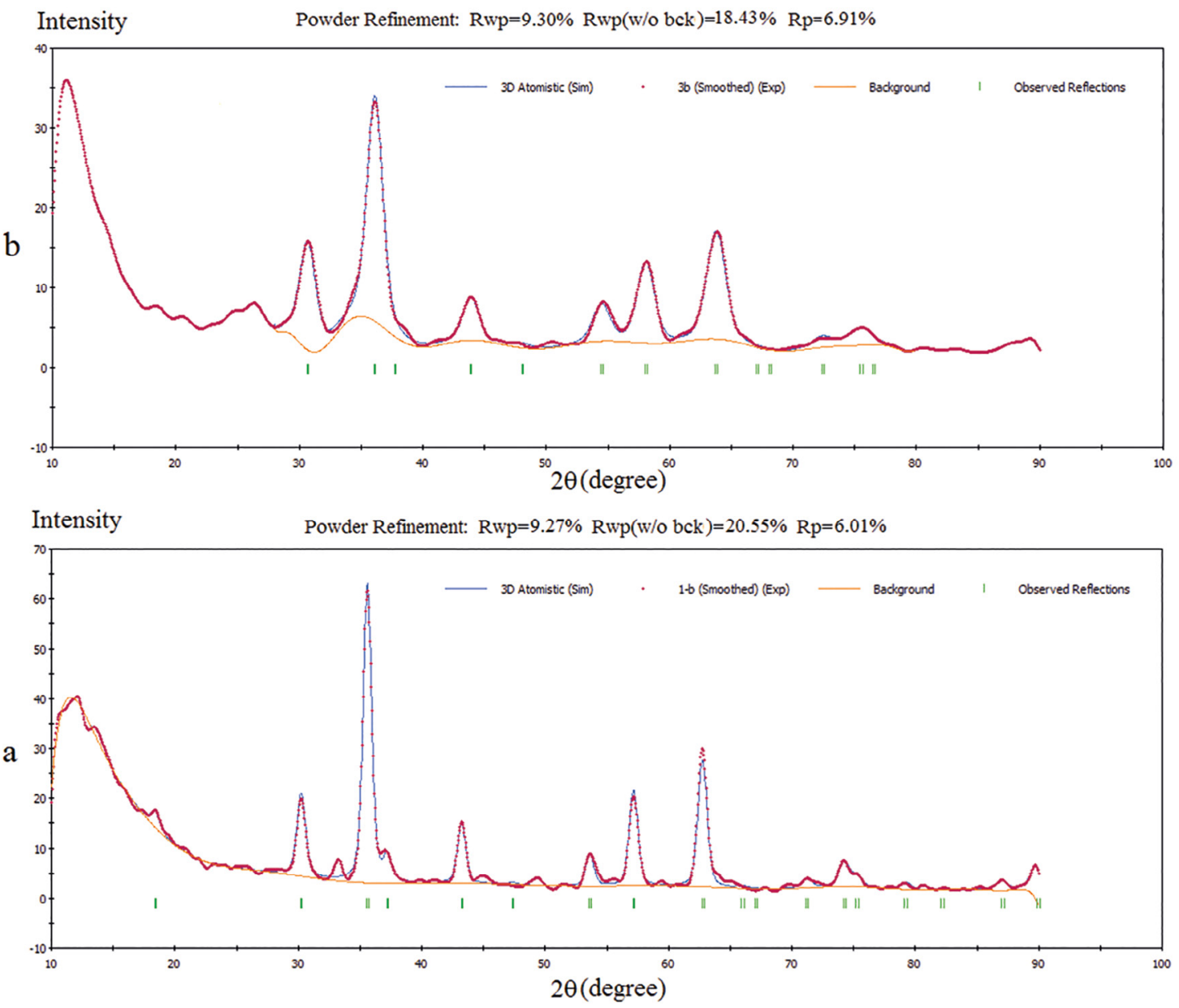

Figure 2. Rietveld plot obtained by using the true instrumental function, a: $\mathrm{CoFe}_{2} \mathrm{O}_{4}, \mathrm{~b}: \mathrm{Al}_{0.44} \mathrm{CoFe}_{1.56} \mathrm{O}_{4}$. 
1/4) for which $u_{\text {idea }}=0.250$ (origin at B-site), while $u^{43}$ give ' $u$ ' assuming centre of symmetry at $(3 / 8,3 / 8,3 / 8)$ for which $u_{\text {idea }}=0.375$ (origin at A-site). These two factors are related by following formula:

$$
u^{\overline{43} m}=u^{3 m}+1 / 8
$$

The radius of the tetrahedral and octahedral sites in a spinel ferrite can be calculated using the following formulae: ${ }^{37,38}$

$$
\begin{array}{r}
R_{A}=a \sqrt{3}\left(u-\frac{1}{4}\right)-R_{0} \quad(5) \\
R_{B}=a\left(3 u^{2}-2.75 u+\frac{43}{64}\right)^{1 / 2}-R_{0}
\end{array}
$$

Where $R_{O}$ is the radius of the oxygen ion $\left(1.32{ }^{\circ} \mathrm{A}\right)$ and $u$ represents the oxygen positional parameter (table 3 ).

Using the lattice constant as well as oxygen parameter (u) of each composite, interatomic distances have been calculated from following equations. ${ }^{39,40}$ The calculated values are presented in Table 3.

$$
d_{A E}=a(2)^{1 / 2}\left(2 u^{\overline{43} m}-\frac{1}{2}\right)
$$

Shared octahedral edge

$$
d_{B E}=a(2)^{1 / 2}\left(1-2 u^{\overline{4} 3 m}\right)
$$

Shared tetrahedral edge

$$
d_{B L}=a\left[3\left(u^{\overline{43 m}}\right)^{2}-\frac{11}{4} u^{\overline{43 m}}+\frac{43}{64}\right]^{1 / 2}
$$

Octahedral bond lenght

$$
d_{A L}=a \sqrt{3}\left(u^{43 m}-\frac{1}{4}\right)
$$

Tetrahedral bond lenght

$$
d_{B E u}=a\left[4\left(u^{\overline{4} 3 m}\right)^{2}-3 u^{\overline{43 m}}+\frac{11}{16}\right]^{1 / 2}
$$

\section{Unshared octahedral edge}

It is observed from Table 3 that the doping with alumina brought about a decrease in the values of $R_{A}, R_{B}$, edge lengths and bond lengths. This could be related to the smaller radius of $\mathrm{Al}^{3+}$ ion as compared to $\mathrm{Fe}^{3+}$ ion. In fact, the ionic radius of the $\mathrm{Al}^{3+}$ ion is $0.050 \mathrm{~nm}$, while the ionic radius of the $\mathrm{Fe}^{3+}$ ions is $0.064 \mathrm{~nm}$.

The interionic distances between the cations (b, c, d, $\mathrm{e}$, and $\mathrm{f}$ ) and between the cation and anion ( $\mathrm{p}, \mathrm{q}, \mathrm{r}$ and $\mathrm{s}$ ) were also calculated using the experimental values of lattice constant (a) and oxygen positional parameters $\left(\mathrm{u}^{3 \mathrm{~m}}\right)$ (Tables 4 and 5) by the following relations: ${ }^{41,42}$

$$
\begin{array}{ll}
\text { M-O } & \text { M-M } \\
p=a(5 / 8-u) & b=(a / 4) 2^{1 / 2}
\end{array}
$$

$$
\begin{array}{rlrl}
q & =a(u-1 / 4) 3^{1 / 2} & c & =(a / 8) 11^{1 / 2} \\
r & =a(u-1 / 8) 11^{1 / 2} & d & =(a / 4) 3^{1 / 2} \\
s & =a(1 / 3 u+1 / 8) 3^{1 / 2} & e & =(3 a / 8) 3^{1 / 2} \\
f & =(a / 4) 6^{1 / 2}
\end{array}
$$

Table 4 indicates that, both interatomic distances between the cation-anion ( $\mathrm{p}, \mathrm{q}, \mathrm{r}$ and $\mathrm{s}$ ) and between the cations ( $\mathrm{b}$, $c, d$, e and f) decrease with alumina doping. This result is accordance with decrease in unit cell volume.

The bond angles $\left(\theta_{1}, \theta_{2}, \theta_{3}, \theta_{4}\right.$ and $\left.\theta_{5}\right)$ were calculated by simple trigonometric principle using the interionic distances with the help of following formula: ${ }^{41,42}$

$$
\begin{gathered}
\theta_{1}=\cos ^{-1}\left[\frac{p^{2}+q^{2}-c^{2}}{2 p q}\right] \\
\theta_{2}=\cos ^{-1}\left[\frac{p^{2}+r^{2}-e^{2}}{2 p r}\right] \\
\theta_{3}=\cos ^{-1}\left[\frac{2 p^{2}-b^{2}}{2 p^{2}}\right] \\
\theta_{4}=\cos ^{-1}\left[\frac{p^{2}+s^{2}-f^{2}}{2 p s}\right] \\
\theta_{5}=\cos ^{-1}\left[\frac{r^{2}+q^{2}-d^{2}}{2 r q}\right]
\end{gathered}
$$

These values are tabulated in Table 5 .

It is observed from Table 5 that angles $\theta_{3}$ and $\theta_{4}$ decrease while $\theta_{1}, \theta_{2}$ and $\theta_{5}$ increase with alumina doping. The observed decrease in $\theta_{3}$ and $\theta_{4}$ indicative of weakening of the B-B interaction while increase in $\theta_{1}, \theta_{2}$ and $\theta 5$ suggest strengthening of the A-B and A-A interactions on $\mathrm{Al}^{3+}$ substitution in the system.

\subsection{Elastic properties}

The elastic constants of solids provide a link between the mechanical and dynamical behaviors of crystals. Cubic crystals have three independent elastic constants: $C_{11}, C_{12}$, and $C_{44}$. In the present work, we studied effect of alumina doping on the elastic constants $\mathrm{Cij}$, bulk moduli B, shear moduli G, 
Young's moduli Y and the Poisson ratio v. Values of these factors are computed using the following relationships: ${ }^{43-45}$

$$
\begin{gathered}
B=\frac{B_{v}+B_{R}}{2}, G=\frac{G_{v}+G_{R}}{2}, \\
B_{v}=B_{R}=\frac{C_{11}+2 C_{12}}{3}(22) \\
G_{R}=\frac{5 C_{44}\left(C_{11}-C_{12}\right)}{4 C_{44}+3\left(C_{11}-C_{12}\right)}, G_{v}= \\
\frac{C_{11}-C_{12}+3 C_{44}}{5}(23) \\
Y=\frac{9 B G}{3 B+G}, v=\frac{3 B-2 G}{2(3 B+G)}
\end{gathered}
$$

Complate set of the calculated elastic constants for two samples are collected in Table 6 .

It can be seen that magnitude of moduli were decreased on $\mathrm{Al}^{3+}$ doping. It is explained on the basis of the replacement of $\mathrm{Fe}^{3+}$ ions with half-filled $\mathrm{d}$-shell $\left(3 \mathrm{~d}^{5}\right)$ by $\mathrm{Al}^{3+}$ ions with a noble gas outer electron shell $\left(2 \mathrm{p}^{6}\right)$ structure which do not contribute to the bond formation.

However it is well known that the cations with a completely filled outer electron shell structure are more stable and less compressible than the cations with a halffilled or a incomplete outer shell. In other word the material is compressed easier when the radius of the ions is longer. Therefore, strength of bonding and magnitude of moduli are expected to decrease. ${ }^{46,47}$

\section{Conclusions}

Pure and $\mathrm{Al}^{3+}$ doped cobalt ferrite nanoparticles were successfully synthesized by sol-gel method and thermally treated at $500^{\circ} \mathrm{C}$ for 3 hours. XRD and the rietveld analysis showed that two composition were formed into single phase cubic spinel structure. Various structural parameters can be determined from x-ray powder diffraction pattern analysis and are found useful to explain other physical properties. The lattice parameters and the crystallite size were found decreasing with $\mathrm{Al}^{3+}$ doping. The strength of the A-B interaction increase while B-B interaction decreases with $\mathrm{Al}^{3+}$ substitution for $\mathrm{Fe}^{3+}$ in the system. Also magnitude of moduli were decreased on $\mathrm{Al}^{3+}$ doping. This is due essentially to the ion size difference among $\mathrm{Al}^{3+}$ and $\mathrm{Fe}^{3+}$ ions.

\section{Acknowledgement}

We are thankful to the Payam Noor University for their support and encouragements.

Table 3. Edge lengths $\left[\mathrm{A}^{\circ}\right]$, bond lengths $\left[\mathrm{A}^{\circ}\right]$, radius of the tetrahedral and octahedral $\left[\mathrm{A}^{\circ}\right]$, and anion parametes $\left[\mathrm{A}^{\circ}\right]$ of Al-Co-Fe-O system

\begin{tabular}{lcccccccccc}
\hline compound & $\mathrm{d}_{\mathrm{Ae}}$ & $\mathrm{d}_{\mathrm{BE}}$ & $\mathrm{d}_{\mathrm{BEu}}$ & $\mathrm{d}_{\mathrm{Al}}$ & $\mathrm{d}_{\mathrm{Bl}}$ & $\mathrm{R}_{\mathrm{A}}$ & $\mathrm{R}_{\mathrm{B}}$ & $\mathrm{U}^{43}$ & $\mathrm{U}^{3}$ \\
\hline $\mathrm{CoFe}_{2} \mathrm{O}_{4}$ & 2.8162 & 3.0352 & 2.9140 & 1.7436 & 2.0948 & 0.4236 & 0.7748 & 0.371 & 0.246 \\
$\mathrm{CoAl}_{0.4} \mathrm{Fe}_{1.6} \mathrm{O}_{4}$ & 2.7918 & 3.0196 & 2.9071 & 1.7098 & 2.0924 & 0.3172 & 0.7724 & 0.370 & 0.245 \\
\hline
\end{tabular}

Table 4. Inter-ionic distances $\left[\mathrm{A}^{\circ}\right]$, of Al-Co-Fe-O system

\begin{tabular}{lccccccccc}
\hline compound & $\mathrm{p}$ & $\mathrm{q}$ & $\mathrm{r}$ & $\mathrm{s}$ & $\mathrm{b}$ & $\mathrm{c}$ & $\mathrm{d}$ & $\mathrm{e}$ & $\mathrm{f}$ \\
\hline $\mathrm{CoFe}_{2} \mathrm{O}_{4}$ & 2.1132 & 1.7436 & 3.3322 & 3.5833 & 2.9411 & 3.4492 & 3.6025 & 5.403 & 5.094 \\
$\mathrm{CoAl}_{0.4} \mathrm{Fe}_{1.6} \mathrm{O}_{4}$ & 2.0961 & 1.7064 & 3.271 & 3.5356 & 2.905 & 3.407 & 3.5592 & 5.338 & 5.033 \\
\hline
\end{tabular}

Table 5. Bond angles (degree) of Al-Co-Fe-O system

\begin{tabular}{lccccc}
\hline compound & $\theta_{1}$ & $\theta_{2}$ & $\theta_{3}$ & $\theta_{4}$ & $\theta_{5}$ \\
\hline $\mathrm{CoFe}_{2} \mathrm{O}_{4}$ & 125.54 & 165.4 & 88.24 & 124.86 & 84.28 \\
$\mathrm{CoAl}_{0.4} \mathrm{Fe}_{1.6} \mathrm{O}_{4}$ & 126.96 & 167.68 & 87.72 & 124.69 & 85.14 \\
\hline
\end{tabular}

Table 6. Elastic constants for Al-Co-Fe-O system

\begin{tabular}{lccccccc}
\hline \multirow{2}{*}{ compound } & $\begin{array}{c}\mathrm{C}_{11} \\
{[\mathrm{PA}]}\end{array}$ & $\begin{array}{c}\mathrm{C}_{12} \\
{[\mathrm{GPA}]}\end{array}$ & $\begin{array}{c}\mathrm{C}_{44} \\
{[\mathrm{GPA}]}\end{array}$ & $\begin{array}{c}\mathrm{B} \\
{[\mathrm{GPA}]}\end{array}$ & $\begin{array}{c}\mathrm{Y} \\
{[\mathrm{GPA}]}\end{array}$ & $\begin{array}{c}\mathrm{G} \\
{[\mathrm{GPA}]}\end{array}$ \\
\hline $\mathrm{CoFe}_{2} \mathrm{O}_{4}$ & 186.08 & 28.6087 & 50.2593 & 81.10 & 178.4627 & 0.1333 & 60.2061 \\
$\mathrm{CoAl}_{0.4} \mathrm{Fe}_{1.6} \mathrm{O}_{4}$ & 157.37 & 12.2987 & 47.8372 & 60.65 & 155.5927 & 0.0725 & 56.5492 \\
\hline
\end{tabular}




\section{References}

1. O'Handley RC. Modern Magnetic Materials - Principles and Applications. Hoboken: John Wiley \& Sons; 2000.

2. Buschow KHJ, ed. Handbook of Magnetic Materials, Vol. 19. Amsterdam: Elsevier, North Holland; 2011.

3. Sun S, Zeng H, Robinson DB, Raoux S, Rice PM, Wang SX, et al. Monodisperse $\mathrm{MFe}_{2} \mathrm{O}_{4}(\mathrm{M}=\mathrm{Fe}, \mathrm{Co}, \mathrm{Mn})$ Nanoparticles. Journal of American Chemical Society. 2004;126(1):273-279.

4. Amstad E, Textor M, Reimhult E. Stabilization and functionalization of iron oxide nanoparticles for biomedical applications. Nanoscale. 2011;3(7):2819-2843.

5. Desantis C, Siegel R, Bandi P, Jemal A. Breast cancer statistics, 2011. CA: A Cancer Journal for Clinicians. 2011;61(6):409-418.

6. Chen J. High Temperature Polyol Synthesis of Super paramagnetic $\mathrm{CoFe}_{2} \mathrm{O}_{4}$ Nanoparticles for Magnetic Resonance imaging Contrast agents. Journal of Inorganic Materials. 2009;24(5):967-972.

7. Bixner O, Lassenberger A, Baurech D, Reimhult E. Complete Exchange of the Hydrophobic Dispersant Shell on Monodisperse Superparamagnetic Iron Oxide Nanoparticles. Langmuir. 2015;31(33):9198-9204.

8. Grunewald TA, Lassenberger A, van Ostrum PDJ, Rennhofer H, Zirbs R, Capone B, et al. Core-Shell Structure of Monodisperse Poly(ethylene glycol)-Grafted Iron Oxide Nanoparticles Studied by Small-Angle X-ray Scattering. Chemistry of Materials. 2015;27(13):4763-4771.

9. Kurzhals S, Zirbs R, Reimhult E. Synthesis and Magneto-Thermal Actuation of Iron Oxide Core-PNIPAM Shell Nanoparticles. ACS Applied Materials \& Interfaces. 2015;7(34):19342-19352.

10. El-Shobaky GA, Turky AM, Mostafa NY, Mohamed SK. Effect of preparation conditions on physicochemical, surface and catalytic properties of cobalt ferrite prepared by coprecipitation. Journal of Alloys and Compounds. 2010;493(1-2):415422.

11. Scheffe JR, Allendorf MD, Coker EN, Jacobs BW, McDaniel AH, Weimer AW. Hydrogen Production via Chemical Looping Redox Cycles Using Atomic Layer Deposition-Synthesized Iron Oxide and Cobalt Ferrites. Chemistry of Materials. 2011;23(8):2030-2038.

12. Pervaiz E, Gul IH, Anwar H. Hydrothermal Synthesis and Characterization of $\mathrm{CoFe}_{2} \mathrm{O}_{4}$ Nanoparticles and Nanorods. Journal of Superconductivity and Novel Magnetism. 2013;26(2):415-424.

13. Kurtan U, Topkaya R, Baykal A, Toprak MS. Temperature dependent magnetic properties of $\mathrm{CoFe}_{2} \mathrm{O}_{4} / \mathrm{CTAB}$ nanocomposite synthesized by sol-gel auto-combustion technique. Ceramics International. 2013;39(6):6551-6558.

14. Sinkó K, Manek E, Meiszterics A, Havancsák K, Vainio U, Peterlik H. Liquid-phase syntheses of cobalt ferrite nanoparticles. Journal of Nanoparticle Research. 2012;14:894-908.

15. Jiang G, Chang Q, Yang F, Hu X, Tang H. Sono-assisted preparation of magnetic ferroferric oxide/graphene oxide nanoparticles and application on dye removal. Chinese Journal of Chemical Engineering. 2015;23(3):510-515.

16. Liu Q, Sun J, Long H, Sun X, Zhong X, Xu Z. Hydrothermal synthesis of $\mathrm{CoFe}_{2} \mathrm{O}_{4}$ nanoplates and nanoparticles. Materials Chemistry and Physics. 2008;108(2-3):269-273.
17. Freitas JC, Branco RM, Lisboa IGO, Costa TP, Campos MGN, Jafelicci Júnior M, et al. Magnetic Nanoparticles Obtained by Homogeneous Coprecipitation Sonochemically Assisted. Materials Research. 2015;18(Suppl. 2):220-224.

18. Ahmed MA, El-Khawlani AA. Enhancement of the crystal size and magnetic properties of Mg-substituted Co ferrite. Journal of Magnetism and Magnetic Materials. 2009;321(13):1959-1963.

19. Rana S, Philip J, Raj B. Micelle based synthesis of cobalt ferrite nanoparticles and its characterization using Fourier Transform Infrared Transmission Spectrometry and Thermogravimetry. Materials Chemistry and Physics. 2010;124(1):264-269.

20. Ayyappan S, Mahadevan SP, Chandramohan P, Srinivasan MP, Philip J, Raj B. Influence of $\mathrm{Co}^{2+}$ Ion Concentration on the Size, Magnetic Properties, and Purity of $\mathrm{CoFe}_{2} \mathrm{O}_{4}$ Spinel Ferrite Nanoparticles. The Journal of Physical Chemistry $C$. 2010;114(14):6334-6341.

21. Meng YY, Liu ZW, Dai HC, Yu HY, Zeng DC, Shukla S, et al. Structure and magnetic properties of $\mathrm{Mn}(\mathrm{Zn}) \mathrm{Fe}_{2-\mathrm{x}} \mathrm{RE}_{\mathrm{x}} \mathrm{O}_{4}$ ferrite nano-powders synthesized by co-precipitation and refluxing method. Journal of Powder Technology. 2012;229:270-275.

22. Deraz NM. Glycine-assisted fabrication of nanocrystalline cobalt ferrite system. Journal of Analytical and Applied Pyrolysis. 2010;88(2):103-109.

23. Shobana MK, Nam W, Choe H. Yttrium-doped cobalt nanoferrites prepared by sol-gel combustion method and its characterization. Journal of Nanoscience and Nanotechnology. 2013;13(5):3535-3538.

24. Chae KP, Lee JG, Kweon HS, Lee YB. The crystallographic, magnetic properties of $\mathrm{Al}$, Ti doped $\mathrm{CoFe}_{2} \mathrm{O}_{4}$ powders grown by sol-gel method. Journal of Magnetism and Magnetic Materials. 2004;283(1):103-108.

25. Oliveira VD, Rubinger RM, Silva MR, Oliveira AF, Rodrigues $\mathrm{G}$, Ribeiro VAS. Magnetic and Electrical Properties of $\mathrm{Mn}_{\mathrm{x}} \mathrm{Cu}_{1}$. ${ }_{x} \mathrm{Fe}_{2} \mathrm{O}_{4}$ Ferrite. Materials Research. 2016;19(4):786-790.

26. Panda RN, Shih JC, Chin TS. Magnetic properties of nanocrystalline Gd- or Pr-substituted $\mathrm{CoFe}_{2} \mathrm{O}_{4}$ synthesized by the citrate precursor technique. Journal of Magnetism and Magnetic Materials. 2003;257(1):79-86.

27. Kambale RC, Song KM, Koo VS, Hur N. Low temperature synthesis of nanocrystalline $\mathrm{Dy}^{3+}$ doped cobalt ferrite: Structural and magnetic properties. Journal of Applied Physics. 2011;110(5):053910.

28. Wang L, Li FS. Mössbauer study of nanocrystalline Ni-Zn ferrite. Journal of Magnetism and Magnetic Materials. 2001;223(3):233-237.

29. Xu S, Shangguan W, Yuan J, Chen M, Shi J. Preparation and Photocatalytic Properties of Magnetically Separable $\mathrm{TiO}_{2}$ Supported on Nickel Ferrite. Chinese Journal of Chemical Engineering. 2007;15(2):190-195.

30. Yousefi MH, Manouchehri S, Arab A, Mozaffari M, Amiri GR, Amighian J. Preparation of cobalt-zinc ferrite $\left(\mathrm{Co}_{0.8} \mathrm{Zn}_{0.2} \mathrm{Fe}_{2} \mathrm{O}_{4}\right)$ nanopowder via combustion method and investigation of its magnetic properties. Materials Research Bulletin. 2010;45(12):1792-1795. 
31. Raghavender AT, Pajic D, Zadro K, Milekovic T, Venkateshwar Rao P, Jadhav KM, et al. Synthesis and magnetic properties of $\mathrm{NiFe}_{2-\mathrm{x}} \mathrm{Al}_{\mathrm{x}} \mathrm{O}_{4}$ nanoparticles. Journal of Magnetism and Magnetic Materials. 2007;316(1):1-7.

32. Smith J, Wijn HPJ. Ferrites. Eindhoven: Philips Technical Library; 1959.

33. Louh R, Reynolds TG, Buchanan RC. Ferrite Ceramics. In: Buchanan RC, ed. Ceramic Materials for Electronics. $3^{\text {rd }}$ Ed. Boca Raton: CRC Press; 2004.

34. Young RA. Introduction to the Rietveld Method. In: Young RA, ed. The Rietveld Method. Oxford: Oxford University Press; 1993.

35. Polvakov NE, Leshina TV, Meteleva ES, Dushkin AV, Konovalova TA, Kispert LD. Enhancement of the Photocatalytic Activity of $\mathrm{TiO}_{2}$ Nanoparticles by Water-Soluble Complexes of Carotenoids. The Journal of Physical Chemistry B. 2010;114(45):14200-14204.

36. Young RA, ed. The Rietveld Method. Oxford: Oxford University Press; 1993.

37. Toby BH. $R$ factors in Rietveld analysis: How good is good enough? Powder Diffraction. 2006;21(1):67-70.

38. Sharma RK, Sebastian V, Lakshmi N, Venugopalan K, Reddy VR, Gupta A. Variation of structural and hyperfine parameters in nanoparticles of Cr-substituted Co-Zn ferrites. Physical Review B. 2007;75(14):144419.

39. Goldman A. Modern Ferrite Technology. $2^{\text {nd }}$ Ed. New York: Springer; 2006
40. Amer MA, El Hill M. Mössbauer and X-ray studies for $\mathrm{Ni}_{0.2} \mathrm{Zn}_{\mathrm{x}} \mathrm{Mg}_{0.8-\mathrm{x}} \mathrm{Fe}_{2} \mathrm{O}_{4}$ ferrites. Journal of Magnetism and Magnetic Materials. 2001;234(1):118-125.

41. Birgani AN, Niyaifar M, Hasanpour A. Study of cation distribution of spinel zinc nano-ferrite by X-ray. Journal of Magnetism and Magnetic Materials. 2015;374:179-181.

42. Bhatu SS, Lakhani VK, Tanna AR, Vasoya NH, Buch JU, Sharma PU, et al. Effect of nickel substitution on structural, infrared and elastic properties of lithium ferrite. Indian Journal of Pure and Applied Physics. 2007;45(7):596-608.

43. Sharifi I, Shokrollahi H, Doroodmand MM, Safi R. Magnetic and structural studies on $\mathrm{CoFe}_{2} \mathrm{O}_{4}$ nanoparticles synthesized by co-precipitation, normal micelles and reverse micelles methods. Journal of Magnetism and Magnetic Materials. 2012;324(10):1854-1861.

44. Beer FP, Johnston ER Jr., DeWolf JT. Mechanics of Materials. New York: McGraw-Hill Higher Education; 2006.

45. Grimvall G. Thermophysical Properties of Materials. $1^{\text {st }}$ Ed. Amsterdam: Elsevier, North Holland; 1999.

46. Bouhemadou A. Theoretical study of the structural, elastic and electronic properties of the $\mathrm{GeX}_{2} \mathrm{O}_{4}(\mathrm{X}=\mathrm{Mg}, \mathrm{Zn}, \mathrm{Cd})$ compounds under pressure. Modelling and Simulation in Materials Science and Engineering. 2008;16(5):055007.

47. Haines J, Léger JM, Bocquillon G. Synthesis and Design of Superhard Materials. Annual Review of Materials Research. 2011;31:1-23. 